Volume 3 Issue 1, March 2019: pp. 85-102. Copyright (c) 2019 HOLREV. Faculty of Law, Halu Oleo University, Kendari, Southeast Sulawesi, Indonesia. ISSN: 2548-1762 | e-ISSN: 2548-1754. Open Access at: http://ojs.uho.ac.id/index.php/holrev/

Halu Oleo Law Review is licensed under a Creative Commons Attribution 4.0 International License, which permits unrestricted use, distribution, and reproduction in any medium, provided the original work is properly cited.

\title{
Analisis Fiqh Lingkungan Terkait Penyalahgunaan Pengelolaan Pertambangan Terhadap Kerusakan Lingkungan Hidup
}

\author{
Analysis of Environmental Fiqh Related to Misuse of Mining Management on \\ Environmental Damage
}

\author{
Muh. Sabaruddin Sinapoy \\ Dosen Fakultas Hukum Universitas Halu Oleo Kendari \\ Email: sabaruddinsinapoy@yahoo.com
}

\begin{abstract}
Efforts in controlling pollution and environmental damage caused by mining activities are rampant activities conducted by companies and communities scattered in some areas have the potential to cause pollution and environmental damage due to the use of heavy metals in binding minerals and mining land into unproductive land. Mining industry activities in addition to having a positive impact because it can be able to meet the needs of people's lives and bring considerable results as a source of foreign exchange, but the other side has a large negative impact that is with many permissions issued, resulting in damage, forest sustainability, loss of flora ecosystem-rare and new fauna and environmental pollution, thus disrupting the health, as well as the loss of local wisdom culture of the surrounding community.
\end{abstract}

Keyword: fiqh environment; mining management; environmental damage

Abstrak: Upaya dalam pengendalian pencemaran dan kerusakan lingkungan hidup akibat pertambangan dilatarbelakangi maraknya aktivitas yang dilakukan perusahaan maupun masyarakat yang tersebar di beberapa wilayah berpotensi menyebabkan pencemaran dan kerusakan lingkungan hidup akibat penggunaan logam berat dalam mengikat mineral dan lahan bekas tambang menjadi lahan tidak produktif. Kegiatan industri pertambangan selain mempunyai dampak positif karena dapat memenuhi kebutuhan hidup masyarakat dan mendatangkan hasil yang cukup besar sebagai sumber devisa, tetapi sisi lain mempunyai dampak negatif cukup besar yaitu dengan banyaknya perizinan yang dikeluarkan, maka mengakibatkan terjadinya kerusakan, kelestarian hutan, hilangnya ekosistem florafauna langka maupun baru dan pencemaran lingkungan, sehingga mengganggu kesehatan, serta hilangnya budaya kearifan lokal masyarakat sekitarnya.

Kata kunci: fiqh lingkungan; pengelolaan pertambangan; kerusakan lingkungan hidup 


\section{PENDAHULUAN}

Indonesia merupakan negara kepulauan (archipelagio state) terbesar di dunia. Secara geografis negara kepulauan nusantara ini terletak di sekitar khatulistiwa antara $94^{\circ} 45^{\prime}$ BT$141^{\circ} 01^{\prime} \mathrm{BT}$ dan dari $06^{\circ} 08^{\prime} \mathrm{LU}-11^{\circ} 05^{\prime} \mathrm{LS}$ serta diapit oleh dua benua yaitu Asia dan Australia dan dua samudera yaitu Pasifik dan Hindia yang membentang dari Barat ke Timur sepanjang $5.110 \mathrm{~km}$ dan dari Utara ke Selatan $1.888 \mathrm{~km} .{ }^{1}$ Wilayah Indonesia enam puluh lima persen (65 \%) dari seluruh wilayahnya ditutupi oleh laut. Luas total perairan laut Indonesia mencapai 5,8 juta $\mathrm{km} 2$, terdiri dari 0,3 juta $\mathrm{km} 2$ perairan teritorial, dan 2,8 juta km2 perairan nusantara, ditambah dengan luas ZEE (Zona Ekonomi Eksklusif Indonesia) sebesar 2,7 juta km2 (UNCLOS, 1982). ${ }^{2}$ Jumlah pulaunya mencapai 17.507 buah, serta memiliki garis pantai sepanjang $81.000 \mathrm{~km}$, merupakan garis pantai terpanjang kedua di dunia setelah Kanada. ${ }^{3}$ Namun, tanpa disadari, laju eksploitasi semakin meningkat dengan didukung oleh kemajuan canggihnya peralatan industri teknologi. Hingga kemudian menyebabkan daya dukung lingkungan terlampaui dan bukan saja dapat mengancam kelestarian SDA itu sendiri, tetapi juga dapat menyebabkan kerusakan lingkungan dan pencemaran.

Seiring dengan hal-hal tersebut di atas, dunia saat ini dicemaskan oleh semakin memburuknya kualitas lingkungan disebabkan oleh eksploitasi besar-besaran terhadap alam baik laut, darat maupun udara. Adanya penggalian secara besar-besaran terhadap berbagai jenis fosil tersebut hanyalah untuk kepentingan kehidupan manusia yang ditandai semakin hari tampak makin tidak efisien dan mengejar kenyamanan belaka, akibatnya mempercepat proses kerusakan lingkungan. ${ }^{4}$ Perlu diketahui juga, bahwa, lingkungan hidup sebagai karunia dan rahmat Allah SWT, kepada rakyat dan bangsa Indonesia. Dalam rangka mendayagunakan Sumber Daya Alam (SDA) untuk memajukan

1 H. Sabarno, Pelaksanaan Administrasi Pemerintahan dan Pengelolaan Pulau-Pulau Indonesia di Wilayah Perbatasan. Dalam O.C. Kaligis \& Associates, Sengketa Sipadan-Ligitan, Mengapa Kita Kalah, Jakarta, 2003, hlm. 60.

2 Etty R. Agoes (ed), Dimanahkah Batas-Batas Wilayah Kita Di Laut?, Jakarta: Departemen Kelautan dan Perikanan, 13 Desember 2000, hlm. 1. Lihat juga, Lusy K. F. R. Gerungan, “Penegakan Hukum Di Wilayah Perairan Indonesia”, Jurnal Lex et Societatis, Vol. IV/No. 5/Mei, Manado: Fakultas Hukum Unsrat, 2016, hlm. 7.

3 Kementerian Agraria dan Tata Ruang/Badan Pertanahan Nasional, Rencana Strategis Direktorat Jenderal Tata Ruang 2015-2019, Jakarta, 2015, hlm. 2.1.

4 M. Abdurrahman, Dinamika Masyarakat Islam Dalam Wawasan Fikih, Bandung: Remaja Rosdakarya, 2002, hlm. 130 . 
kesejahteraan umum seperti diamanatkan dalam Undang-Undang Dasar 1945 dan untuk mencapai kebahagiaan hidup berdasarkan Pancasila. ${ }^{5}$

Indonesia sendiri mempunyai Sumber Kekayaan Alam (SKA) yang sangat melimpah. Areal lautan dan hutannya merupakan paling luas di dunia, tanah subur, pemandangan alam begitu indah, wilayah perairannya sangat luas, dengan komoditi ikan sangat besar turut berperan penting dalam kehidupan manusia. ${ }^{6}$ Artinya, kekayaan alam tersebut diberikan dan digunakan dengan sebaik-baiknya agar manusia dapat melangsungkan kehidupannya dengan memperhatikan keseimbangan dan pelestarian lingkungan alam agar tetap terjaga. Tetapi, alam diperlakukan tidak adil, manusia dengan tabiatnya yang serakah dan rakus dalam memanfaatkan kekayaan alam tersebut tidak lagi peduli kepada fungsi-fungsi alam itu sendiri.

Padahal manusia telah diberikan peran di muka bumi sebagai khalifah, mengurus, memanfaatkan, dan memelihara, baik langsung maupun tidak langsung amanah dari Allah SWT, berupa bumi dan segala isinya, untuk dipergunakan sebaik-baiknya dengan menjaga keberlangsungan, keseimbangan dan kelestarian alam guna kepentingan seluruh makhluk hidup ciptaan Allah SWT di muka bumi ini. Lebih celakanya lagi, pesan Tuhan tersebut diabaikan. Namun apa yang terjadi, kemajuan tersebut justru membawa dampak buruk/petaka terhadap kelangsungan lingkungan, yaitu berupa bencana alam. ${ }^{7}$ Sebagaimana di dalam Al-Qur'an telah dikatakan, bahwa bencana alam dan krisis lingkungan adalah ulah dari manusia itu sendiri. Hal demikian diterangkan dalam Surat Ar-Rum (30): 41, Artinya: "Telah nampak kerusakan di darat dan di laut disebabkan karena perbuatan tangan manusia, supaya Allah merasakan kepada mereka sebahagian dari (akibat) perbuatan mereka, agar mereka kembali (ke jalan yang benar).”

Ayat di atas menerangkan, bahwa dampak dari terjadinya kerusakan di muka bumi ini disebabkan oleh ulah tangan manusia. Faktanya, ayat tersebut telah memberikan peringatan kepada kita semua, bahwa hakikat manusia tersebut adalah sering merusak. Hasil dari perbuatan manusia tersebut, bilamana dikaitkan dengan aktivitasnya dalam pengelolaan pertambangan adalah kerusakan terhadap ekosistem alam, juga berdampak

5 Siswanto Sunarso, Hukum Pidana Lingkungan Hidup dan Strategi Penyelesaian Sengketa, Jakarta: Rineka Cipta, 2005, hlm. 1-2.

6 Akhmad Fauzi, Ekonomi Sumber Daya Alam dan Lingkungan Teori dan Aplikasi, cet. Ke-1, Jakarta: Gramedia Pustaka Utama, 2010, hlm. 98.

7 Yusuf Al-Qaradhawi, Islam Agama Ramah Lingkungan, cet. Ke-1, Jakarta: Pustaka Al-Kautsar, 2001, hlm. 24. 
pada manusia itu sendiri. Seperti, banjir, longsor, kebakaran hutan, kurangnya pasokan makanan, menurunnya pendapatan ekonomi masyarakat, hilangnya lapangan pekerjaan/lahan garapan, musnahnya habitat flora-fauna dan kekeringan yang semakin hari semakin parah ini bukan salah siapa pun melainkan salah dari manusia itu sendiri. Di dalam pandangan Islam, ${ }^{8}$ sesuatu bencana yang menimpa atau membinasakan, kemalangan dan kejadian yang tidak diinginkan lazim disebut dengan musibah.

Kesadaran manusia akan pentingnya alam bagi dirinya sudah tidak dihiraukan lagi. Mengambil kekayaan alam melalui pertambangan dengan merusak seluruh fasilitas lingkungan tidak menjadi masalah, asalkan perut bumi telah diambil hasil-hasilnya untuk memperkaya dan memenuhi kebutuhan hidup sehari-hari. Manusia juga telah menghilangkan keseimbangan alam dan memutus satu mata rantai kehidupan alam dari aktivitasnya mengeksploitasi alam untuk pengerukan kekayaan dari dasar perut bumi. ${ }^{9}$ Selanjutnya, dalam eksploitasi dan pemanfaatan barang tambang tersebut sudah lama dilakukan oleh manusia. ${ }^{10}$ Sehingga perusakan dan pencemaran lingkungan kian memprihatinkan dari tahun ke tahun, bahkan tingkat kerusakan dan pencemaran lingkungan semakin meluas.

Selain itu juga, pada proses pengambilan dan penggalian sering kali tidak sesuai dengan prosedur, apalagi pertambangan yang dilakukan oleh masyarakat sering sekali tidak memperhatikan lokasi pertambangan, para pemilik atau masyarakat bertindak semena-mena (sesuka hatinya), dengan tidak menghiraukan lagi beberapa ketentuan peraturan perundang-undangan tentang larang menggunakan bahan kimia khususnya mercury. Sehingga, kekhawatiran akan meningkatnya aktivitas kerusakan dan pencemaran lingkungan hidup dari kegiatan penambangan khususnya emas, nikel, dan lain sebagainya tidak terlepas dari penggunaan zat kimia. Sementara penggunaan mercury telah dilarang dalam UU Nomor 32 Tahun 2009 tentang Perlindungan dan Pengelolaan Lingkungan Hidup Pasal 98 ayat (1). Berdasarkan uraian tersebut di atas dapat dikatakan bahwa alam atau lingkungan sangat berpengaruh bagi keberlangsungan makhluk hidup terutama hidup manusia, karena manusia berinteraksi dengan lingkungannya. Oleh karena itu, pengelolaan, pemanfaatan dan pelestarian SDA oleh masyarakat Indonesia

8 Hasan Muafif Ambarry (dkk), Ensiklopedia Islam, Jilid: 3, Jakarta: Ichtiar Baru van Hoeve, 1999, hlm. 308.

9 Niniek Suparna, Pelestarian, Pengelolaan dan Penegakan Hukum Lingkungan, Cet. Ke-2, Jakarta: Sinar Grafika, 1994, hlm. 124.

10 Ibid, Niniek Suparna, hlm. 134. 
harus dilaksanakan dan dijalankan dengan jelas, bijak dan tegas sesuai amanat Pasal 33 Undang-Undang Dasar Negara Republik Indonesia Tahun 1945.

\section{METODE PENELITIAN}

Jenis penelitian/pendekatan yang digunakan oleh penulis adalah penelitian hukum normatif empirik. Penelitian hukum normative menurut Peter Mahmud Marzuki ${ }^{11}$ yaitu penelitian hukum yang dilakukan dengan pendekatan undang-undang (statute approach), pendekatan kasus (case approach), pendekatan historis (historical approach), pendekatan komparatif (comparative approach), dan pendekatan konseptual (conceptual approach). Sedangkan normative empiris, ${ }^{12}$ yakni penelitian yuridis dilakukan dengan cara meneliti bahan pustaka yang merupakan data sekunder dan juga disebut penelitian kepustakaan. Penelitian hukum empiris dilakukan dengan cara meneliti di lapangan yang merupakan data primer.

\section{ANALISIS DAN PEMBAHASAN}

Ruang Lingkup Pengelolaan Pertambangan Bagi Masyarakat, Lingkungan dan

\section{Negara}

Masyarakat dunia tergantung dari SDA, karena bahan-bahan ini adalah mutlak untuk eksistensi hidup manusia. Sehingga, cara SDA itu diolah dan digali serta bagaimana metode penggunaannya akan membawa pengaruh besar terhadap cara hidup dan struktur masyarakat. ${ }^{13}$ Pemanfaatan SDA untuk pembinaan kesejahteraan tersirat juga dalam tujuan bernegara. Tujuan bangsa Indonesia adalah membentuk masyarakat adil dan makmur berdasarkan Pancasila. ${ }^{14}$ Maka, salah satu kekayaan alam yang patut dikelola untuk sebesar-besarnya kemakmuran rakyat adalah kekayaan sumber daya energi dan mineral. Potensi sumber daya dan cadangan mineral metalik tersebar di 437 lokasi di Indonesia bagian Barat dan Timur, seperti tembaga dan emas di Papua, emas di Nusa Tenggara, nikel di Sulawesi dan Kepulauan Indonesia Timur, bauksit dan batu bara di Kalimantan dan mineral lainnya yang tersebar di berbagai tempat. ${ }^{15}$ Maka, lingkungan

11 Peter Mahmud Marzuki, Penelitian Hukum, Jakarta: Kencana Prenada Media Group, 2005, hlm. 93.

12 Ronny Hanitijo Soemitro, Metode Penelitian Hukum dan Jurimetri, Jakarta: Ghalia Indonesia, 1990, hlm. 36.

13 J.A. Katili, Sumber Daya Alam untuk Pembangunan Nasional, Jakarta: Ghalia Indonesia, 1983, hlm. 29.

14 Mahfud MD, Membangun Politik Hukum Menegakkan Konstitusi, Jakarta: Rajawali Press, 2011, hlm. 17.

15 Gatot Supramono, Hukum Pertambangan Mineral dan Batu Bara di Indonesia, Jakarta: Rineka Cipta, 2012, hlm. 1. 
hidup beserta kekayaan SDA di dalamnya seyogyanya merupakan faktor utama yang memberikan pengaruh secara signifikan terhadap proses dinamika bermasyarakat. ${ }^{16}$

Sejalan dengan pernyataan tersebut di atas, pengelolaan lingkungan hidup merupakan upaya manusia untuk memperbesar manfaat lingkungan, sedangkan risiko lingkungan diperkecil. Kondisi alam menimbulkan sikap hidup yang bertumpu pada pandangan, bahwa manusia adalah sekedar salah satu unsur lingkungan hidup, yang mempunyai kecenderungan untuk mempertahankan lingkungan hidup dalam keadaan alami. ${ }^{17}$ UU Nomor 23 Tahun 1997 Tentang Pengelolaan Lingkungan Hidup memberikan definisinya tentang pengelolaan lingkungan hidup adalah upaya terpadu untuk melestarikan fungsi lingkungan hidup yang meliputi kebijaksanaan penataan, pemanfaatan, pengembangan, pemeliharaan, pemulihan, pengawasan, dan pengendalian lingkungan hidup. ${ }^{18}$ Konsep ini sangat relevan dengan prinsip penyelenggaraan pengelolaan lingkungan hidup untuk mewujudkan pembangunan berkelanjutan, harus didasarkan pada norma hukum dengan memperhatikan tingkat kesadaran masyarakat. ${ }^{19}$

Jadi, pengembangan hukum yang mengintegrasikan pertimbangan lingkungan dan pembangunan sosial dan ekonomi dianggap sebagai bagian dari konsep pembangunan, maka teori hukum sebagai sarana pembaharuan masyarakat merupakan bagian dari pembahasan hukum pembangunan berkelanjutan. ${ }^{20}$ Teori hukum sebagai sarana pembangunan dan pembaharuan masyarakat tersebut dapat dianggap sebagai gagasan awal perkembangan pembangunan berkelanjutan. ${ }^{21}$ Adanya konsep pembangunan lingkungan yang berkelanjutan tersebut, tidak terlepas dari keberadaan SDA sebagai sumber daya yang esensial bagi kelangsungan hidup manusia. ${ }^{22}$ Namun, setelah melalui berbagai proses perdebatan dan mosi, maka ditetapkan Peraturan Pemerintah Pengganti

16 Koentjaraningrat, Sejarah Teori Antropologi I, Jakarta: Universitas Indonesia Press, 1990, hlm. 1.

17 Op.cit, Niniek Suparna, hlm. 134.

18 Undang-Undang Nomor 23 Tahun 1997 Pasal 1 Tentang Pengelolaan Lingkungan Hidup.

19 Loc.cit, Siswanto Sunarso, hlm, 1-4.

20 M. Daud Silalahi, Perkembangan Hukum Lingkungan Indonesia: Tantangan dan Peluang, Bandung: Pidato Pengukuhan Jabatan Guru Besar Fakultas Hukum Universitas Padjadjaran, 2000, tanpa halaman dan Danis Goulet, The Cruel Choice; A New Concept in The Theory of Development, New York: Atheneum Press, 1971, tanpa halaman.

21 Mochtar Kusumaatmadja yang membahas peranan hukum sebagai alat atau sarana pembaharuan/pembangunan masyarakat, bandingkan dengan teori hukum R. Pound yang membahas law as tool of social engineering. Juga dengan tulisan M. Daud Silalahi, Perkembangan Hukum Lingkungan Indonesia: Tantangan dan Peluang, Bandung: Pidato Pengukuhan Jabatan Guru Besar Fakultas Hukum Universitas Padjadjaran, 2000, tanpa halaman.

22 Fauzi Akhmad, Ekonomi Sumber Daya Alam dan Lingkungan, Jakarta: Gramedia Pustaka Utama, 2004, hlm. 12. 
Undang-Undang (Perpu) Nomor 37 Tahun 1960 dan Peraturan Pemerintah Pengganti Undang-Undang Nomor 44 Tahun 1960 yang mengatur khusus tentang minyak dan gas bumi. ${ }^{23}$

Beberapa peraturan tentang pertambangan zaman dulu tersebut, menunjukkan bahwa sektor ini memiliki ruang lingkup cukup strategis dan penting untuk kelangsungan suatu negara maupun masyarakat. Salah satu SDA yang kita miliki adalah mineral emas, nikel, biji besi, aspal, batu bara, perak dan lain sebagainya, yang termasuk dalam golongan sumber daya yang tidak dapat diperbaharui (non renewable). Sektor pertambangan merupakan salah satu andalan untuk mendapatkan devisa. ${ }^{24}$ Tidak hanya mendapatkan devisa, namun dampak dari kegiatan pertambangan itu sendiri bisa negatif ataupun positif. Menurut Muhammad dalam Ali Sulto ${ }^{25}$, dapat bersifat positif bagi daerah pengusaha pertambangan, sedangkan Noor dalam Ali Sulto ${ }^{26}$ mengatakan, bahwa kegiatan pertambangan bersifat negatif terhadap ekosistem daerah setempat.

\section{Kebijakan Pengelolaan Pertambangan Terhadap Kerusakan Lingkungan Hidup}

Terkait dengan permasalahan-permasalahan pertambangan tidak dapat dipisahkan dengan hukum pertambangan itu sendiri. Hukum pertambangan adalah "hukum yang mengatur tentang penggalian atau pertambangan biji-biji dan mineral-mineral dalam tanah".27 Pertambangan adalah urusan pekerjaan dan sebagainya yang mengenai tambang. ${ }^{28}$ Menurut Badan Koordinasi Penanaman Modal (BKPM) pertambangan adalah kegiatan pengambilan endapan bahan tambang berharga dan bernilai ekonomis dari dalam kulit bumi, pada permukaan bumi, di bawah permukaan air, baik secara mekanis maupun manual. ${ }^{29}$ Hal tersebut telah dijelaskan dalam UU Nomor 4 Tahun 2009 tentang Pertambangan Mineral dan Batubara pada Pasal 1 ayat (1), ayat (6) dan ayat (19), juga dalam black law dictionary, mining law diartikan sebagai "the act of appropriating a mining

23 Bambang Yunianto dkk, Kebijakan Sektor Energi dan Sumber Daya Mineral dan Implikasinya terhadap Pertambangan Emas dalam Penambangan dan Pengolahan Emas di Indonesia, Bandung: Puslitbang Teknologi Mineral dan Batubara, 2004, hlm. 19.

24 UW Soelistijo, Beberapa Aspek Penerapan Manajemen Moderen Dalam Rangka Menunjang Pengembangan Sumberdaya Alam Berkelanjutan Di Indonesia, Bandung: Seminar Intern Fakultas Teknik UNISBA, 2008, hlm. 3.

25 Ali Sulto, Dampak Aktivitas Pertambangan Bahan Galian Golongan C Terhadap Kondisi Kehidupan Masyarakat Desa, Skripsi, Bogor: Institut Pertanian Bogor, 2011, hlm. 13.

26 Ibid, Ali Sulto, hlm. 13.

27 Undang-Undang Di Bidang Pertambangan, Cet. Pertama, Jakarta: Eko Jaya, 2009, hlm. 4.

28 Badudu Zairi, Kamus Umum Bahasa Indonesia, Pustaka Sinar Harapan, Jakarta, 1994, hlm. 1413.

29 Badan Koordinasi Penanaman Modal (BKPM), Kategori C, Pertambangan dan Penggalian, Badan Koordinasi Penanaman Modal (BKPM), https://www.bkpm.go.id. diakses pada tanggal 1 Mei 2018. 
claim (parcel of land containing precious metal in its soil or rock) according to certain astablished rule". 30

Kekayaan alam merupakan sumber daya yang digolongkan berdasarkan ketersediaannya. Menurut pembagiannya, dapat digolongkan menjadi dua, yaitu: SDA yang dapat diperbarui dan SDA yang tidak dapat diperbarui. SDA yang dapat diperbaharui adalah jenis SDA yang jika persediaannya habis dalam waktu tidak terlalu lama dan relatif mudah dapat tersedia kembali melalui reproduksi atau pengembang biakan. Sedangkan, yang dimaksud dengan SDA yang tidak dapat diperbarui adalah minyak bumi, gas alam, mineral dan batu bara. ${ }^{31}$ Maka, setiap kegiatan pengelolaan SDA seharusnya tidak boleh merusak SDA yang lainnya. Apabila terjadi kerusakan hutan, maka akan menghancurkan keanekaragaman SDA lainnya yang berada di dalam hutan yaitu air, tanah, beraneka ragam tumbuh-tumbuhan serta hewan dari yang kecil sampai besar. Selain itu juga, pertambangan mineral dan batu bara memiliki sifat yang khas yakni tidak dapat diperbaharui dan cenderung bersifat merusak, di antaranya akan menyebabkan deforestasi, hutan gundul, daratan bolong-bolong, serta terjadinya pengikisan terhadap humus tanah, adanya lubang-lubang bekas penambangan mengakibatkan lahan tidak produktif dan lain sebagainya.

Walaupun kegiatan penambangan sudah diatur secara jelas dalam undang-undang, akan tetapi permasalahan lingkungan tetap saja terjadi, hal ini dikarenakan penggalian bahan mineral baik logam maupun bukan logam tidak terkendali dan tidak terawasi... 32 Jadi, tidak ada aktivitas pertambangan tidak merusak. Dimulai dari tahap eksplorasi membuka areal pertambangan saja sudah merusak hutan dan lingkungan, sampai pada tahap akhir yaitu eksploitasi maupun tahap pemrosesan mineral (pemurnian hasilnya). ${ }^{33}$

Selanjutnya, di sisi lainnya juga bermunculan berbagai konflik sosial yang memakan korban sebagai akibat sampingan dari bisnis ini masih terus terjadi. Dari catatan

30 Diana Yusyanti, “Aspek Perizinan Dibidang Hukum Pertambangan Mineral Dan Batubara Pada Era Otonomi Daerah”, Jurnal Penelitian Hukum De Jure, Vol. 16 No. 3, September 2016, hlm. 312.

31 Ibid, hlm. 310.

32 P.M. Hasibuan, "Dampak Penambangan Bahan Galian Golongan C Terhadap Lingkungan Sekitarnya Di Kabupaten Deli Serdang”, Jurnal Equality 11 (1), 2006, hlm. 26-32. Lihat juga dalam Dini Widyasmarani Suherman, Dyah Tjahyandari Suryaningtyas, Sri Mulatsih, “Dampak Penambangan Pasir Terhadap Kondisi Lahan Dan Air Di Kecamatan Sukaratu Kabupaten Tasikmalaya”, Jurnal Pengelolaan Sumberdaya Alam dan Lingkungan, Available online at: Vol. 5 No. 2 (Desember 2015), hlm. 99-105 http://journal.ipb.ac.id/index.php/jpsl/, e-ISSN: 2460-5824, Bogor: Sekolah Pascasarjana Institut Pertanian, 2015, hlm. 99.

33 I.N. Dyahwanti, Kajian Dampak Lingkungan Kegiatan Penambangan Pasir Pada Daerah Sabuk Hijau Gunung Sumbing di Kabupaten Temanggung, (Tesis), Sekolah Pascasarjana, Semarang: Universitas Dipenogoro. 2007, hlm. 106. 
Wahana Lingkungan Hidup Indonesia (WALHI), sepanjang 2011 saja terjadi setidaknya 26 kali konflik antara masyarakat dengan perusahaan tambang. ${ }^{34}$ Oleh karena itu, secara teoritis operasi pertambangan dibagi menjadi dua bentuk yakni open pit (penambangan terbuka) dan underground (penambangan bawah tanah, termasuk pengelolaan dengan model gua-gua). Tercatat, bahwa pertambangan menduduki peringkat ketiga sebagai konflik SDA dengan luas lahan seluas 197.365,90 ha. ${ }^{35}$

Walaupun kebijakan pemerintah melalui peraturan perundang-undangan sekian banyak telah terbit, namun kegiatan pertambangan tersebut merupakan kegiatan yang komprehensif dan memerlukan luas tanah yang tidak sempit. Terkait dengan kegiatan pertambangan, khususnya Pasal 135 sampai Pasal 138 UU No. 4 Tahun 2009. Pada Pasal 135-136 ayat (1) dikatakan, bahwa pemegang IUP Eksplorasi atau IUPK Eksplorasi hanya dapat melaksanakan kegiatannya setelah mendapat persetujuan dari pemegang hak atas tanah. Selanjutnya dalam Pasal 135 sebagai syarat mutlak bagi perusahaan pertambangan. Selain itu juga, kegiatan pertambangan merupakan kegiatan skala nasional yang dapat mewujudkan kemakmuran dan kesejahteraan rakyat secara berkeadilan. Maria SW Sumardjono $^{36}$ mengungkapkan bahwa perwujudan keadilan sosial dalam bidang pertanahan dapat dilihat pada prinsip-prinsip dasar UUPA, yakni prinsip "negara menguasai", prinsip penghormatan terhadap hak atas tanah masyarakat hukum adat, asas fungsi sosial semua hak atas tanah, prinsip landreform, prinsip perencanaan dalam penggunaan tanah dan upaya pelestariannya, dan prinsip rasionalitas.

\section{Penyalahgunaan Pengelolaan Pertambangan Berdampak Kerusakan Lingkungan Hidup}

Pada prinsipnya, pengelolaan lingkungan hidup berasaskan pelestarian kemampuan lingkungan yang serasi dan seimbang untuk menunjang pembangunan yang berkesinambungan bagi peningkatan kesejahteraan manusia. Setiap orang mempunyai hak dan kewajiban untuk berperan serta dalam rangka pengelolaan lingkungan hidup. ${ }^{37}$

\footnotetext{
34 Aji Wihardandi, Pemerintah Siapkan Langkah Reaktif Cegah Dampak Negatif Tambang Lebih Jauh, Mongabay, https://www.mongabay.co.id/2012/08/08/pemerintah-siapkan-langkah-reaktif-cegahdampak-negatif-tambang-lebih-jauh/, diakses tanggal 7 Mei 2018.

35 Sumber Konsorsium Pembaruan Agraria (KPA), 2013.

36 Laporan Penelitian Integrasi Hak Ulayat ke dalam Yurisdiksi UUPA, Depdagri FH UGM, tahun 1978, dalam Maria SW Sumardjono, Kebijakan Pertanahan Antara Regulasi dan Implementasi, Jakarta: Kompas, 2005, hlm. 42.

37 Niniek Suparna, Op.cit, hlm. 58.
} 
Akan tetapi, setiap kegiatan pertambangan yang dilakukan secara besar-besaran telah mengubah morfologi atau bentang alam pada perbukitan akibat dari penggalian akan berubah menjadi dataran. Selain merusak tanah (terjadinya perubahan fisik tanah pada area pertambangan), solium atau lapisan tanah yang terbentuk selama jutaan tahun menjadi hilang dan rusak (seharusnya unsur tanah tetap ada), biota tanah dan tutupan tanaman tahunan 100\% hilang termasuk liatnya juga, tanaman susah hidup, terjadinya perubahan pada hayati, erosi yang beragam, maupun pertambangan juga menyebabkan hilangnya hutan. Artinya, setiap area yang digunakan untuk tambang tidak ada tanaman sama sekali, serta musnahnya atau berkurangnya ekologis/lingkungan pada lokasi tambang, maupun hilangnya vegetasi yang berada di atasnya. Juga, menimbulkan kerugian ataupun dampak lingkungan bagi masyarakat dan menimbulkan dampak pencemaran lingkungan dan kerusakan lingkungan. Jadi indikator kerusakan tanah akibat adanya usaha aktivitas pertambangan telah terpenuhi.

Maka, tindakan perusakan dan pencemaran lingkungan hidup tersebut dapat dikategorikan sebagai tindak pidana (jinayah) apabila perbuatan tersebut memenuhi unsur-unsur tindak pidana. Beberapa pasal KUHP, mengatur mengenai hal-hal yang dikaitkan dengan lingkungan hidup. Tetapi dengan perkembangan zaman, jika hanya mengandalkan KUHP sebagai instrumen penegakan hukum pidana bagi lingkungan, tentu tidak akan memadai dan efektif. ${ }^{38}$ Mengenai sanksi pidana bagi pelaku tindak pidana perusakan lingkungan hidup di jelaskan dalam BAB XV UUPPLH 2009.39 Ada dua tindak pidana yang diperkenalkan dalam UUPPLH, yaitu delik materiil (generic crimes) dan delik formil (specific crimes). Delik materill (generic crimes) merupakan perbuatan melawan hukum yang menyebabkan perusakan atau pencemaran lingkungan hidup. Perbuatan melawan hukum seperti itu tidak harus dihubungkan dengan pelanggaran aturan-aturan hukum administrasi, sehingga delik materiil ini disebut juga sebagai Administrative Independent Crimes (selanjutnya disingkat AIC).40 Delik materiil dalam ketentuan UndangUndang Nomor 32 Tahun 2009 tentang Perlindungan dan Pengelolaan Lingkungan Hidup terdapat pada Pasal 98, Pasal 99 dan Pasal 112.

\footnotetext{
38 N.H.T. Siahaan, Hukum Lingkungan, cet. Ke-2, Jakarta: Pancuran Alam, 2009, hlm. 353.

39 Sukanda Husin, Penegakan Hukum Lingkungan Indonesia, cet. Ke-2, Jakarta: Sinar Grafika, 2009, hlm. 121.

40 Ibid, hlm. 121.
} 


\section{Konsep Hukum Islam Tentang Pengelolaan Pertambangan Terhadap Lingkungan}

\section{Hidup}

Alam raya telah diciptakan Allah SWT dalam keadaan yang sangat harmonis, serasi, dan memenuhi kebutuhan makhluk. Allah SWT telah menjadikannya baik, bahkan memerintahkan hamba-hambanya untuk memperbaikinya. Kehidupan alam dalam pandangan Islam berjalan di atas prinsip keselarasan dan keseimbangan. Artinya, apabila ada satu unit atau bagian yang rusak pasti menyebabkan unit atau bagian lain menjadi rusak pula. Prinsip keteraturan yang serasi dan perhitungan yang tepat semacam ini seharusnya menjadi pegangan atau landasan berpijak bagi manusia dalam menjalani kehidupan di muka bumi ini. Allah SWT telah menciptakan manusia ${ }^{41}$ di bumi. Sehingga, manusia menduduki posisi sentral dalam mengelola dan mengatur bumi ${ }^{42}$ beserta segala isinya secara baik dan benar, guna memenuhi kebutuhan hidupnya demi mencapai kemaslahatan (kesejahteraan).43 Sebaliknya, kesalahan dalam pengelolaan bumi dan segala isinya tidak saja akan mengancam kelangsungan dan kelestarian bumi, tetapi juga dapat berakibat fatal bagi kehancuran umat manusia itu sendiri.

Kamus Besar Bahasa Indonesia, lingkungan diartikan sebagai daerah (kawasan dan sebagainya) yang termasuk di dalamnya, sedangkan lingkungan alam diartikan sebagai keadaan (kondisi, kekuatan) sekitar, yang mempengaruhi perkembangan dan tingkah laku organisme. $^{44}$ Lingkungan adalah segala sesuatu di sekeliling makhluk hidup yang berpengaruh dan mendukung pada ekosistensi dan keberlanjutan kehidupannya. ${ }^{45}$ Dalam fiqh lingkungan merupakan sebagai perangkat aturan tentang perilaku ekologis manusia yang ditetapkan oleh ulama yang berkompeten berdasarkan dalil yang terperinci untuk tujuan mencapai kemaslahatan kehidupan yang bernuansa ekologis. ${ }^{46}$ Artinya, Islam memberikan panduan yang jelas tentang bagaimana pelestarian lingkungan sebagai daya dukung bagi kesejahteraan masyarakat. Di sisi lain Al-Qur'an juga menunjukkan keharusan

41 Kata خليفة diterjemahkan dengan “pengganti”. Lihat Ahmad Warson Munawwir, AlMunawwir Kamus ArabIndonesia, Yogyakarta: UPBIK Pondok Pesantren Al-Munawwir, 1984, hlm. 392.

42 Bumi terdiri dari wilayah laut, darat, dan udara. Dalam tulisan ini, kajian difokuskan pada pengelolaan laut, yang merupakan salah satu bagian dari bumi.

43 Ahmad Yusam Thobroni, "Al-Fikra”, Jurnal Ilmiah Keislaman, Vol. 7, No. 2, Juli-Desember 2008, tanpa nomor halaman.

44 Pusat Bahas Departemen Pendidikan Nasional, Kamus Besar Bahasa Indonesia Edisi Ketiga, Jakarta: Balai Pustaka, 2002, hlm. 675.

45 Yusuf Al-Qaradhawi, Islam Agama Ramah Lingkungan, cet. Ke-1, Jakarta: Pustaka Al-Kautsar, 2001, hlm. 5.

46 Sukarni, Fikih Lingkungan Hidup Perspektif Ulama Kalimantan Selatan, Jakarta: Kementerian Agama RI, 2011, hlm. 16. 
untuk membina hubungan yang apresiatif dengan alam berbentuk sikap menghargai dalam maknanya yang lebih spiritual ${ }^{47}$ sebagaimana di tegaskan dalam QS. Al-An'am (6/55):38; QS. Al-Isra' (17/50): 44; dan QS. Al-Ra'd (13/96):13. Oleh karena itu, aktivitas manusia kepada setiap perbuatan ataupun tindakannya terkait dengan fungsi untuk menjaga kelestarian alam dan lingkungan, dikarenakan tempat-tempat tersebut merupakan bagian yang tidak terpisahkan dari bumi sebagai tempat tinggal manusia, sebagaimana dalam QS. Al-Baqarah (2/87):29 (Dia-lah Allah yang menjadikan segala yang ada di bumi untuk kamu)." 48 Dalam ayat ini Allah SWT menegaskan, bahwa bumi dan segala isinya, termasuk wilayah bumi yang berupa lautan, diciptakan dengan kodrat untuk manusia. Karena itu, manusia dapat menguasai dan memanfaatkan potensi alam untuk kepentingan tugas dan kehidupannya. ${ }^{49}$

Dalam konteks inilah, Islam sebagai agama yang memiliki ajaran spiritual mampu untuk mengingatkan sekaligus mengatur tata hubungan antara manusia dan alam. ${ }^{50}$ Nilainilai yang terkandung di dalam Al-Qur'an dan Hadist dapat dijadikan sebagai landasan berpikir dan bertindak bagi umat Islam dalam menyikapi kerusakan lingkungan, dengan kekayaan nilai yang terkandung dalam ayat-ayat Al-Qur'an maupun Hadist Nabi Muhammad SAW, dapat menjadi pendorong bagi umat Islam dalam melestarikan alam dan lingkungan. ${ }^{51}$ Selain itu juga, Islam memiliki sistem keyakinan yang jelas bahwa Allah SWT telah menjadikan SDA dan lingkungan daya dukung bagi kehidupan semua makhluk hidup yang ada di bumi. Oleh karena itu, Islam meyakini pelestarian dan pemanfaatan lingkungan SDA di sektor pertambangan termasuk bagian integral dari sistem berimanan seseorang. Maka, prinsip tersebut merupakan tujuan daripada terbentuknya syari'at dalam berbuat kebajikan dan menghindari kemungkaran yang diformulasikan dalam kulliyat al-khamsah (lima kemaslahatan dasar) yang menjadi tegaknya kehidupan umat manusia. Terkait dengan konservasi lingkungan tersebut diuraikan oleh Yusuf al-Qardhawi, ${ }^{52}$ sebagai

\footnotetext{
47 Nurcholis Madjid, Pintu-Pintu Menuju Tuhan, Jakarta: Paramadina, 1995, hlm. 148-149.

48 Departemen Agama RI, Al Qur'an (2/87):29.

49 Abd. Muin Salim, Metode Dakwah untuk Menanggulangi Lahan Kritis: Sebuah Telaah Qurani, Laporan Penelitian, dalam Perumusan Model Dakwah dalam Pelaksanaan Penanggulangan Lahan Kritis di Sulawesi Selatan, Ujung Pandang, Kerjasama BAPPEDA Tkt. I Sulawesi Selatan dengan P3M IAIN Alauddin, 1989/1990, hlm. 86.

50 Jumarddin La Fua, "Aktualisasi Pendidikan Islam dalam Pengelolaan Lingkungan Hidup Menuju Kesalehan Ekologi”, Jurnal Al-Ta'dib, Vol. 7 No. 1 Januari-Juni 2014, hlm. 22.

51 Maulana Ismail, Pendidikan Lingkungan Prespektif Al-Qur"an dan Aktualisasinya Dalam Pendidikan Islam, Skripsi, Yogyakarta: Jurusan Pendidikan Islam Fakultas Tarbiyah UIN Sunan Kalijaga, 2009, hlm. 32.

52 M. Ghufron, Rekontruksi Paradigma Fikih Lingkungan, Surabaya: IAIN Sunan Ampel Press, 2012, hlm. 10 dan 96.
} 
berikut: (1). Menjaga lingkungan sama dengan hifdz al-din; (2). Menjaga lingkungan sama dengan hifdz al-nafs; (3). Menjaga lingkungan sama dengan hifdz al-nasl; (4). Menjaga lingkungan sama dengan hifdz al-aql; dan (5). Menjaga lingkungan sama dengan hifdz almaal.

Dalam hal itu, fiqih lingkungan atau fiqh al-bi'ah adalah bagian dari fiqih kontemporer yang dimaksudkan untuk menyikapi isu-isu lingkungan dari perspektif yang lebih praktis dengan memberikan patokan-patokan (hukum dan regulasi) berinteraksi dengan lingkungan. Pemulihan atau rehabilitasi lingkungan yang sudah rusak merupakan bagian lain yang dalam substansi fiqh al-bi'ah adalah konservasi lingkungan yang sudah rusak. Hukum pelestarian lingkungan hidup adalah fardhu kifayah. ${ }^{53}$ Allah SWT berfirman dalam Al-Qur'an Surat Al-A'raf (7): 56. Artinya: "Dan janganlah kamu membuat kerusakan di muka bumi, sesudah (Allah) memperbaikinya dan berdoalah kepada-Nya dengan rasa takut (Tidak akan diterima) dan harapan (akan dikabulkan). Sesungguhnya rahmat Allah amat dekat kepada orang-orang yang berbuat baik."

Penegasan dari uraian kalimat tersebut di atas kemudian kembali di ingatkan oleh Rasulullah SAW di dalam Hadits, "Dari Abu Hurairah berkata: Rasulullah SAW bersabda, "Jika amanah disia-siakan, maka tunggulah saatnya (kehancuran). Abu Hurairah bertanya: Bagaimana cara amanat disia-siakan wahai Rasulullah? Rasul menjawab, 'Jika suatu perkara diserahkan kepada orang yang bukan ahlinya, maka tunggulah saatnya" (HR. Bukhari). Berdasarkan uraian tersebut, maka, konsep Islam tentang pengelolaan SDA khususnya di sektor pertambangan dalam pengertian luas merupakan upaya untuk merevitalisasi misi asal ekologi, back to basic ecology. Dengan demikian, visi Islam tentang SDA adalah visi SDA yang utuh secara menyeluruh, holistik integralistik yang diproyeksikan mampu menjadi garda depan dalam pengembangan kesadaran melestarikan keseimbangan ekosistem. Selain itu juga, Islam memperhatikan seluruh kebutuhan hidup manusia, tidak terkecuali dengan pertambangan.

Dalam konteks pemahaman tersebut menunjukkan, bahwa sesuatu yang ada dibumi dan dilangit telah diberikan hanya kepada manusia sebagai hamba-Nya sebagai manifestasi daripada kekuasaan Allah SWT. Jadi, pemberian tersebut merupakan karunia yang tidak dapat dilepaskan terkait dengan pandangan Islam melalui Al-Qur'an sebagai

53 Ali Yafie, Merintis Fiqh Lingkungan Hidup, Jakarta: Ufuk Press, 2006, hlm. 200. 
rahmatan lil alamin. Artinya Islam juga mempunyai kewajiban untuk menjaga lingkungan dan menghormati alam semesta yang mencakup jagat raya yang di dalamnya. ${ }^{54}$

Sebagai sesama anggota komunitas ekologis yang setara, manusia digugah untuk mencintai, menyayangi dan melestarikan alam semesta dan seluruh isinya tanpa diskriminasi dan tanpa dominasi. Oleh karenanya, dibutuhkan konsep kesadaran, kearifan dan kepedulian terhadap alam khususnya sebagai bagian yang terintegral dalam konsep pelestarian alam dan lingkungan guna melindungi segenap bangsa Indonesia untuk mencapai kesejahteraan berkeadilan sosial. 55 Dengan demikian, dapat dinyatakan bahwa fiqh lingkungan dalam menjaga fungsi-fungsi alam maupun lingkungan di sektor pertambangan dalam Islam sebagai kristalisasi dari kesadaran, kearifan dan kepedulian yang menjadi bagian integral dari keberimanan masyarakat beragama Islam. Di samping itu juga, meletakan dasar hubungan antara manusia dengan alam beserta segala isinya dalam Al-Qur'an dijelaskan dalam kerangka istikhlaf (tugas-tugas kekhalifahan manusia). Al-Qur'an menegaskan bahwa manusia ditugaskan Tuhan menjadi khalifah di muka bumi ini QS. Al-Baqarah (2/87):30.56 Demikianlah, tuntunan Allah SWT terkait dengan keharusan sikap manusia terhadap lingkungan yang senantiasa untuk memelihara dan melestarikan lingkungan alam sekitarnya, serta tidak membuat kerusakan.

\section{KESIMPULAN}

Fenomena bencana lingkungan yang terjadi akhir-akhir ini seperti banjir, kekeringan dan tanah longsor mengindikasikan bahwa kemampuan atau daya dukung sumber daya lahan dan lingkungan semakin rendah. Kerusakan lahan disebabkan oleh banyak faktor antara lain deforestasi. Sebab, banyak penggunaan lahan sebagai sumber daya tidak memperhatikan lingkungan hidup.

Bila hal tersebut dikaitkan dan berpedoman dengan Al-Qur'an dan Hadits sangatlah jelas telah diatur mengenai masalah lingkungan hidup dalam pertambangan batu bara dan mineral, etika lingkungan hidup terhadap upaya perlindungan lingkungan hidup, dimana manusia menentukan untuk berakhlak yang baik dan menjaga hubungan alam sebagai ciptaan Allah SWT serta menyadari hakikat dan ketaatan manusia itu terhadap perintah

54 Nurcholis Madjid, Loc.cit, hlm. 148-149.

55 Mujiono Abdillah, Agama Ramah Lingkungan Perspektif Alquran, Cet. 1. Jakarta: Paramadina, 2001, hlm. 60.

56 M. Quraish Shihab, Tafsir al-Mishbah: Pesan, Kesan, dan Keserasian Al-Qur'an, Vol. I, Jakarta: Lentera Hati, 2000, hlm. 295. 
Allah SWT melalui Al-Qur'an dan Hadist. Jadi, dampak yang terjadi dari adanya pencemaran lingkungan hidup yang kini sedang melanda dunia bukanlah melalui persoalan teknis, ekonomis, politik, hukum, dan sosial-budaya semata. Melainkan diperlukan upaya penyelesaian dari berbagai perspektif, termasuk salah satunya adalah perspektif fiqh. Mengingat, fiqh pada dasarnya merupakan perantara etika dan perundangundangan (legal formal). Sehingga, fiqh merupakan "pedoman" (secara etis) di satu sisi dan "peraturan" (secara normatif) untuk keselamatan.

\section{Daftar Pustaka}

\section{Buku}

Abdillah, Mujiono, Agama Ramah Lingkungan Perspektif Alquran, Cet. 1. Jakarta: Paramadina, 2001.

Abdurrahman, M, Dinamika Masyarakat Islam Dalam Wawasan Fikih, Bandung: Remaja Rosdakarya, 2002.

Agoes, Etty R. (ed), Dimanahkah Batas-Batas Wilayah Kita Di Laut?, Jakarta: Departemen Kelautan dan Perikanan, 13 Desember 2000.

Akhmad, Fauzi, Ekonomi Sumber Daya Alam dan Lingkungan, Jakarta: Gramedia Pustaka Utama, 2004.

Al-Qaradhawi, Yusuf, Islam Agama Ramah Lingkungan, cet. Ke-1, Jakarta: Pustaka AlKautsar, 2001.

Ambarry, Hasan Muafif, (dkk), Ensiklopedia Islam, Jilid: 3, Jakarta: Ichtiar Baru van Hoeve, 1999.

Fauzi, Akhmad, Ekonomi Sumber Daya Alam dan Lingkungan Teori dan Aplikasi, cet. Ke-1, Jakarta: Gramedia Pustaka Utama, 2010.

Ghufron, M, Rekontruksi Paradigma Fikih Lingkungan, Surabaya: IAIN Sunan Ampel Press, 2012.

Goulet, Danis, The Cruel Choice; A New Concept in The Theory of Development, New York: Atheneum Press, 1971.

Husin, Sukanda, Penegakan Hukum Lingkungan Indonesia, cet. Ke-2, Jakarta: Sinar Grafika, 2009.

Kaligis, O.C., \& Associates, Sengketa Sipadan-Ligitan, Mengapa Kita Kalah, Jakarta, 2003.

Katili, J.A., Sumber Daya Alam untuk Pembangunan Nasional, Jakarta: Ghalia Indonesia, 1983. 
Kementerian Agraria dan Tata Ruang/Badan Pertanahan Nasional, Rencana Strategis Direktorat Jenderal Tata Ruang 2015-2019, Jakarta, 2015.

Koentjaraningrat, Sejarah Teori Antropologi I, Jakarta: Universitas Indonesia Press, 1990. Madjid, Nurcholis, Pintu-Pintu Menuju Tuhan, Jakarta: Paramadina, 1995.

Marzuki, Peter Mahmud, Penelitian Hukum, Jakarta: Kencana Prenada Media Group, 2005. MD, Mahfud, Membangun Politik Hukum Menegakkan Konstitusi, Rajawali Press, Jakarta, 2011.

Munawir, Ahmad Warson, AlMunawwir Kamus Arab-Indonesia, Yogyakarta: UPBIK Pondok Pesantren Al-Munawwir, 1984.

Shihab, M. Quraish, Tafsir al-Mishbah: Pesan, Kesan, dan Keserasian Al-Qur'an, Vol. I, Jakarta: Lentera Hati, 2000.

Siahaan, N.H.T, Hukum Lingkungan, cet. Ke-2, Jakarta: Pancuran Alam, 2009.

Soemitro, Ronny Hanitijo, Metode Penelitian Hukum dan Jurimetri, Jakarta: Ghalia Indonesia, 1990.

Sukarni, Fikih Lingkungan Hidup Perspektif Ulama Kalimantan Selatan, Jakarta: Kementerian Agama RI, 2011.

Sumardjono, Maria SW, Kebijakan Pertanahan Antara Regulasi dan Implementasi, Jakarta: Kompas, 2005.

Sunarso, Siswanto, Hukum Pidana Lingkungan Hidup dan Strategi Penyelesaian Sengketa, Jakarta: Rineka Cipta, 2005.

Suparna, Niniek, Pelestarian, Pengelolaan dan Penegakan Hukum Lingkungan, cet. Ke-2, Jakarta: Sinar Grafika, 1994.

Supramono, Gatot, Hukum Pertambangan Mineral dan Batu Bara di Indonesia, Jakarta: Rineka Cipta, 2012.

Yafie, Ali, Merintis Fiqh Lingkungan Hidup, Jakarta: Ufuk Press, 2006.

Yunianto, Bambang, dkk., Kebijakan Sektor Energi dan Sumber Daya Mineral dan Implikasinya Terhadap Pertambangan Emas Dalam Penambangan dan Pengolahan Emas di Indonesia, Bandung: Puslitbang Teknologi Mineral dan Batubara, 2004.

\section{Kamus}

Pusat Bahas Departemen Pendidikan Nasional, Kamus Besar Bahasa Indonesia Edisi Ketiga, Jakarta: Balai Pustaka, 2002.

Zairi, Badudu, Kamus Umum Bahasa Indonesia, Jakarta: Pustaka Sinar Harapan, 1994. 


\section{Jurnal/Karya Ilmiah}

Dyahwanti, I.N, Kajian Dampak Lingkungan Kegiatan Penambangan Pasir Pada Daerah Sabuk Hijau Gunung Sumbing di Kabupaten Temanggung, Tesis, Sekolah Pascasarjana, Semarang: Universitas Dipenogoro, 2007.

Fua, Jumarddin La, "Aktualisasi Pendidikan Islam dalam Pengelolaan Lingkungan Hidup Menuju Kesalehan Ekologi", Jurnal Al-Ta'dib, Vol. 7 No. 1 Januari-Juni 2014.

Gerungan, Lusy K. F. R, Penegakan Hukum Di Wilayah Perairan Indonesia, Jurnal Lex et Societatis, Vol. IV/No. 5/Mei, Fakultas Hukum Unsrat, Manado, 2016.

Hasibuan, P.M, “Dampak Penambangan Bahan Galian Golongan C Terhadap Lingkungan Sekitarnya Di Kabupaten Deli Serdang”, Jurnal Equality 11 (1), 2006.

Ismail, Maulana, Pendidikan Lingkungan Prespektif Al-Qur"an dan Aktualisasinya Dalam Pendidikan Islam, Skripsi, Jurusan Pendidikan Islam Fakultas Tarbiyah UIN Sunan Kalijaga, 2009.

Purnaweni, Hartuti, “Kebijakan Pengelolaan Lingkungan Di Kawasan Kendeng Utara Provinsi Jawa Tengah", Jurnal Ilmu Lingkungan, Volume 12 Issue 1, Program Studi Ilmu Lingkungan Program Pascasarjana UNDIP, Semarang, 2014.

Salim, Abd. Muin, "Metode Dakwah untuk Menanggulangi Lahan Kritis: Sebuah Telaah Qurani", Laporan Penelitian, dalam Perumusan Model Dakwah dalam Pelaksanaan Penanggulangan Lahan Kritis di Sulawesi Selatan, Ujung Pandang, Kerjasama BAPPEDA Tkt. I Sulawesi Selatan dengan P3M IAIN Alauddin, 1989/1990.

Silalahi, M. Daud, Perkembangan Hukum Lingkungan Indonesia: Tantangan dan Peluang, Bandung: Pidato Pengukuhan Jabatan Guru Besar Fakultas Hukum Universitas Padjadjaran, 2000.

Soelistijo, UW, “Beberapa Aspek Penerapan Manajemen Moderen Dalam Rangka Menunjang Pengembangan Sumber Daya Alam Berkelanjutan Di Indonesia”, Seminar Intern Fakultas Teknik UNISBA, Bandung, 2008.

Suherman, Dini Widyasmarani, Dyah Tjahyandari Suryaningtyas, Sri Mulatsih, "Dampak Penambangan Pasir Terhadap Kondisi Lahan Dan Air Di Kecamatan Sukaratu Kabupaten Tasikmalaya", Jurnal Pengelolaan Sumberdaya Alam dan Lingkungan Available online at: Vol. 5 No. 2 (Desember 2015), 5 e-ISSN: 2460-5824, Sekolah Pascasarjana Institut Pertanian Bogor, 2015.

Sulto, Ali, Dampak Aktivitas Pertambangan Bahan Galian Golongan C Terhadap Kondisi Kehidupan Masyarakat Desa, Skripsi, Bogor: Institut Pertanian Bogor, 2011. 
Thobroni, Ahmad Yusam, “Al-Fikra”, Jurnal Ilmiah Keislaman, Vol. 7, No. 2, Juli-Desember 2008.

Yusyanti, Diana, “Aspek Perizinan Dibidang Hukum Pertambangan Mineral Dan Batubara Pada Era Otonomi Daerah", Jurnal Penelitian Hukum De Jure, Vol. 16 No. 3, September, Jakarta, 2016.

\section{Internet}

Badan Koordinasi Penanaman Modal (BKPM), Kategori C, Pertambangan dan Penggalian, Badan Koordinasi Penanaman Modal (BKPM), https://www.bkpm.go.id. diakses pada tanggal 1 Mei 2018

Wihardandi, Aji, Pemerintah Siapkan Langkah Reaktif Cegah Dampak Negatif Tambang Lebih Jauh, Mongabay, https://www.mongabay.co.id/2012/08/08/pemerintahsiapkan-langkah-reaktif-cegah-dampak-negatif-tambang-lebih-jauh/, diakses tanggal 7 Mei 2018.

\section{Perundang-Undangan}

Undang-Undang Nomor 5 Tahun 1960 Tentang Peraturan Dasar Pokok-pokok Agraria.

Undang-Undang Nomor 11 Tahun 1967 Tentang Ketentuan-ketentuan Pokok Pertambangan

Undang-Undang Nomor 32 Tahun 2009 tentang Perlindungan Lingkungan Hidup.

Undang-Undang Nomor 4 Tahun 2009 Tentang Pertambangan Mineral Dan Batubara. 